Original Research Paper

\title{
Pemanfaatan Eceng Gondok (Eichhornia Crassipes) untuk Briket Sebagai Bahan Bakar Energi Alternatif di Kelurahan Panji Sari, Lombok Tengah
} \author{
Nova Fitriani ${ }^{5}$, Risky Khawiyu Pasya ${ }^{5}$ \\ ${ }^{I}$ Fakultas Keguruan dan Ilmu Pendidikan Universitas Mataram, Mataram, Indonesia \\ ${ }^{2}$ Fakultas Hukum Universitas Mataram, Mataram, Indonesia \\ ${ }^{3}$ Fakultas Ekonomi dan Bisnis Universitas Mataram, Mataram, Indonesia \\ ${ }^{4}$ Fakultas Teknik Universitas Mataram, Mataram, Indonesia \\ ${ }^{5}$ Jurusan Ilmu Komunikasi, Mataram, Indonesia
}

Eka Junaidi $^{1 *}$, Agif Suryadi², Chika Nur Narulita², Ghennia Dzinur Arninda ${ }^{2}$, Lalu Wahri Suganda², Mutiara Rizkiandini Putri², Ahmad Kadarisman ${ }^{3}$, Cokorda Werdiyatna $\mathbf{S}^{3}$, Dinda Rizki Karina Sari $^{3}$, M. Iqbal Ferdiansyah ${ }^{3}$, Baiq Haya Ulya Rifada ${ }^{4}$, Gugus Putra Pamungkas ${ }^{4}$, Harkees Hirvad ${ }^{5}$,

https://doi.org/10.29303/jpmpi.v3i2.942

Sitasi: Junaidi, E., Suryadi, A., Narulita, C. N., Arninda, G. D., Suganda, L. W., Putri, M. R., Kadarisman, A., Werdiyatna S, C., Sari, D. R. K., Ferdiansyah, M. I., Rifada, B. H. U., Pamungkas, G. P., Hirvad, H., Fitriani, N \& Pasya, R. K. (2021). Pemanfaatan Eceng Gondok (Eichhornia Crassipes) untuk Briket Sebagai Bahan Bakar Energi Alternatif di Kelurahan Panji Sari, Lombok Tengah. Jurnal Pengabdian Magister Pendidikan IPA, 4(3)

Article history

Received: 31 Juli 2021

Revised: 6 September 2021

Accepted: 7 September 2021

*Corresponding Author:

Eka Junaidi,

Fakultas Keguruan dan Ilmu

Pendidikan, Universitas

Mataram, Mataram, Indonesia

Email: ekajuned@unram.ac.id

\begin{abstract}
Panji Sari merupakan kelurahan yang terletak di sekitar Bendungan Batujai yang terbagi menjadi enam lingkungan, yaitu Lingkungan Bukal Malang, Gelondong, Harapan Baru, Kemulah, Darul Falah Selatan, dan Darul Falah Utara. Letak geografis Panji Sari yang berdekatan dengan Bendungan Batujai, mengakibatkan tumbuhan eceng gondok banyak ditemukan di wilayah Panji Sari, khususnya Lingkungan Bukal Malang. Eceng gondok (Eichhornia crassipes) adalah tanaman yang hidup mengapung di air dan kadang-kadang berakar dalam tanah. Eceng gondok (Eichornia crassipes) berkembang biak dengan sangat cepat, baik secara vegetatif maupun generatif. Akibat pertumbuhannya yang cepat, eceng gondok sering kali menjadi gulma yang menganggu suatu perairan termasuk juga di wilayah kelurahan Panji Sari. Keberadaan eceng gondok yang ditemukan dalam jumlah besar menjadi sangat potensial sebagai bahan baku utama pembuatan briket. Pembuatan briket merupakan upaya mengubah keberadaan eceng gondok sebagai bahan bakar energi terbarukan, menjadi solusi dalam upaya 'zero waste' serta dapat meningkatkan nilai ekonomi masyarakat Kelurahan Panji Sari. Pembuatan briket menggunakan eceng gondok sebagai bahan utama yang ditunjang dengan bahan lain dari kulit biji kenari, sekam padi, ranting kayu, serta tepung tapioka sebagai perekatnya. Hasil dari pembuatan briket eceng gondok dapat dimanfaatkan masyarakat sebagai pengganti arang batok kelapa yang digunakan masyarakat dalam kehidupan sehari-hari sebagai bahan bakar serta pembuatan briket akan dapat memberikan nilai ekonomis tinggi bagi masyarakat khususnya di Kelurahan Panji Sari.
\end{abstract}

Keywords: eceng gondok; briket; energi terbarukan, zero waste.

\section{Pendahuluan}

Eceng gondok (Eichhornia crassipes) adalah tanaman yang hidup mengapung di air dan kadangkadang berakar dalam tanah. Pertumbuhan yang cepat, eceng gondok dapat menjadi gulma di air maka eceng gondok dapat menutupi permukaan air dan menimbulkan masalah pada lingkungan.

Selain merugikan karena cepat menutupi permukaan air, eceng gondok ternyata juga 
bermanfaat karena mampu menyerap zat organik, anorganik serta logam berat lain yang merupakan bahan pencemar (Ratnani, 2012).

Eceng gondok dikategorikan ke dalam jenis tumbuhan invasive, dapat mengancam ekosistem, menurunkan jumlah spesies asli, dan menimbulkan dampak negatif pada aspek sosial ekonomi, mengurangi kadar oksigen akibat Proses evapotranspirasi tanaman, pendangkalan, rusaknya habitat perikanan, dan mengganggu transportasi air. Oleh karena itu, diperlukan inovasi pemanfaatan eceng gondok, agar pertumbuhan eceng gondok lebih terkendali.

Salah satu pemanfaatan eceng gondok adalah sebagai bahan bakar briket (Hendra, 2011). Briket adalah sebuah blok bahan yang dapat dibakar yang digunakan sebagai bahan bakar untuk memulai dan mempertahankan nyala api (Pratama, 2019). Bahan baku briket diketahui dekat dengan masyarakat pertanian karena biomassa limbah hasil pertanian dapat dijadikan briket. Penggunaan briket, terutama briket yang dihasilkan dari biomassa, dapat menggantikan penggunaan bahan bakar fosil (Dahdah, 2020).

Briket memiliki harga yang murah dibandingkan bahan bakar jenis lainnya sehingga penggunaannya dalam dunia industri dapat memberikan penghematan biaya (Billak, 2016). Penggunaan briket diketahui memberikan manfaat dari sisi pengeluaran usaha. Dewasa ini, minat pasar terhadap usaha kuliner grill juga menjadi pertimbangan dalam pembuatan briket eceng gondok karena diharapkan briket eceng gondok dapat digunakan sebagai bahan bakar alternatif (Ariyanto dkk, 2014)

Selain itu, dari sisi pelestarian lingkungan briket jauh lebih ramah lingkungan dibandingkan bahan bakar fosil (Serevina, dkk, 2021). Bahanbahan yang digunakan juga merupakan bahan sisa sehingga pemanfaatan briket eceng gondok juga mampu menjadi solusi dari limbah sampah organik sesuai dengan tema yang diusung oleh kelompok KKN Panji Sari.

Proses pembuatannya briket yang relative mudah ditiru juga diharapkan mampu memotivasi masyarakat untuk meneruskan inovasi ini sehingga keberlangsungan program pemanfaatan eceng gondok menjadi briket ini dapat terjaga dan menjadi solusi bagi upaya mengurangi pertumbuhan eceng gondok di wilayah Panji Sari.

\section{Metode}

Metode pelaksanaan yang dilakukan dalam kegiatan KKN (Kuliah Kerja Nyata) ini melalui serangkaian kegiatan yang dilaksanakan di Kelurahan Panji Sari, Lombok Tengah, diantaranya : 1). Tahap persiapan yang terdiri atas koordinasi dengan pihak kelurahan. Selain itu sebagai tahap awal kegiatan ini, kami menyiapkan bahan-bahan untuk pembuatan Briket; 2). Tahap Pelaksanaan kegiatan berupa pembuatanan video tutorial pembuatan Briket dari eceng gondok; 3). Tahap penguploadan video dan disebar ke masyarakat melalui akun youtube KKN Panji Sari; 4). Tahap pelaporan yang merupakan bagian akhir kegiatan yang berisi informasi keterkaitan antara tingkat antusias masyarakat setelah menonton video tutorial pembuatan Briket dari eceng gondok.

\section{Hasil dan Pembahasan}

Pada kegiatan ini, akan dilakukan upaya mengurangi sampah enceng gondok yang ada di lokasi KKN Pani Sari sebagai sebuah usaha inovasi (penanganan sampah) sehingga enceng gondok yang dianggap sampah dapat memiliki fungsi sebagai bahan bakar alternative (dalam bentuk Briket) dan memiliki tambahan nilai ekonomi bagi masyarakat sekitar karena produk briket enceng gondok dapat dijadikan pengganti bahan bakar arang konvensional.

\subsection{Tahapan Pembuatan Briket}

Tahapan-tahapan pada proses pembuatan briket Enceng Gondok, antara lain, Pengeringan Bahan, Pencampuran bahan, Pembakaran Bahan-Bahan, Pencampuran Tepung, Pembentukan Briket, Penjemuran Briket serta Uji Coba Produk Briket yang sudah dihasilkan.

\section{A. Pengeringan Bahan}

Hal pertama yang dilakukan dalam membuat Briket yaitu mengeringkan semua bahan hingga bahan-bahan tersebut tidak memiliki kandungan air. Bahan-bahan yang dikeringkan antara lain yaitu eceng gondok, ranting kayu, sekam padi, dan kulit biji kenari. 


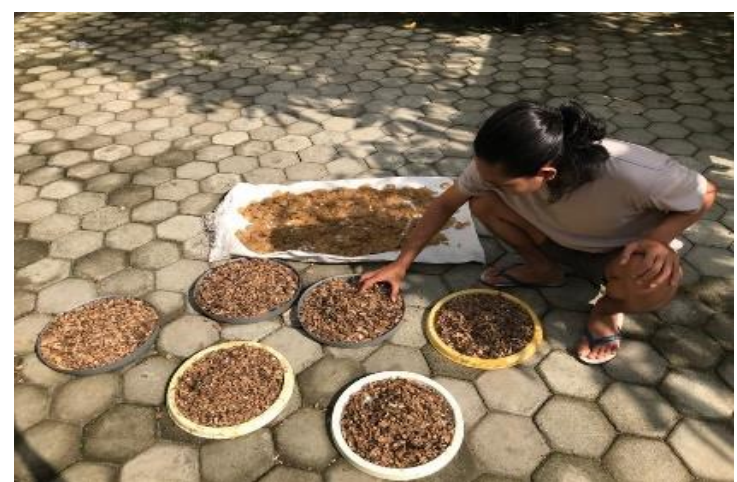

\section{B. Pencampuran Bahan}

Setelah semua bahan dikeringkan, bahanbahan seperti eceng gondok, sekam padi, dan kulit biji kenari dicampur menjadi satu didalam wadah, untuk selanjutnya dibakar menggunakan minyak tanah.

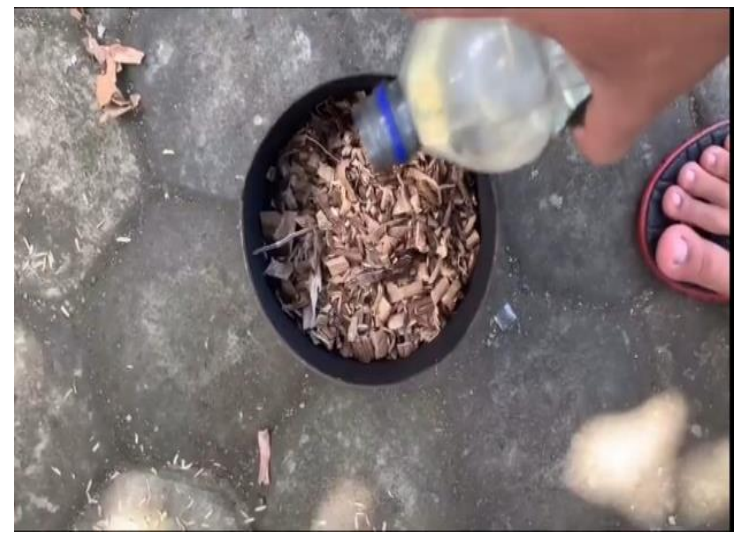

\section{Pembakaran Bahan-Bahan}

Selanjutnya semua bahan dibakar menggunakan minyak tanah. Kemudian tunggu bahan bahan tersebut hingga berwarna hitam dan memiliki tekstur yang agak kasar. Kurang lebih waktu yang dibutuhkan dalam proses pembakaran ini sekitar 1 jam.

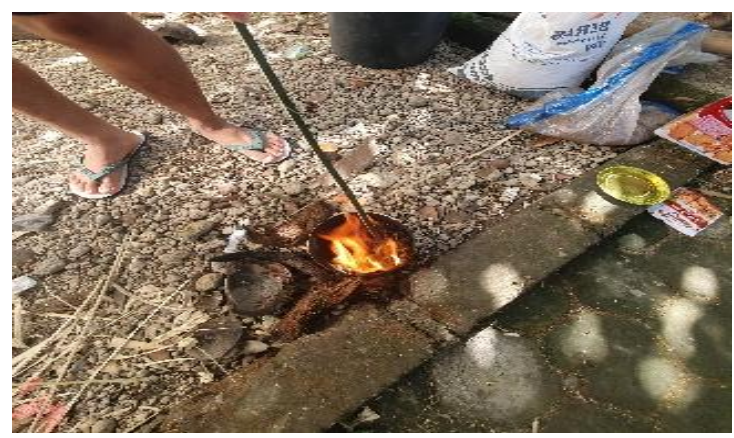

\section{Pencampuran Tepung}

Bahan-bahan yang sudah selesai dibakar, kemudian dicampur dengan ranting kayu yang sudah ditumbuk, tepung Tapioka dan air hangat. Setelah itu bahan tersebut diaduk-aduk agar mudah dibentuk.

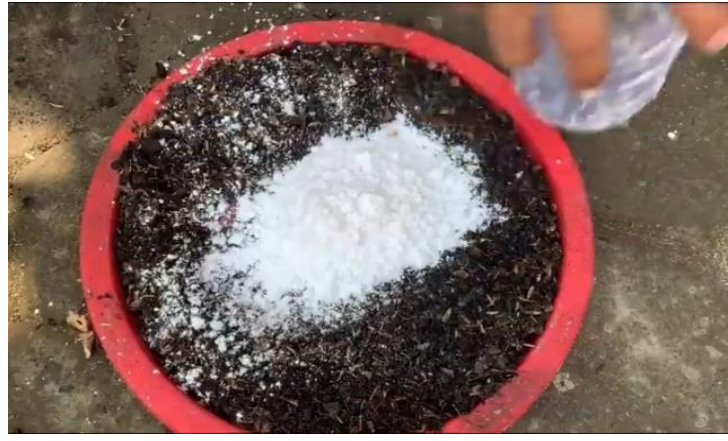

\section{E. Pembentukan Briket}

Setelah tercampur rata, bahan-bahan tersebut kemudian dibentuk menjadi bola-bola kecil agar Briket lebih mudah menyala saat dibakar.

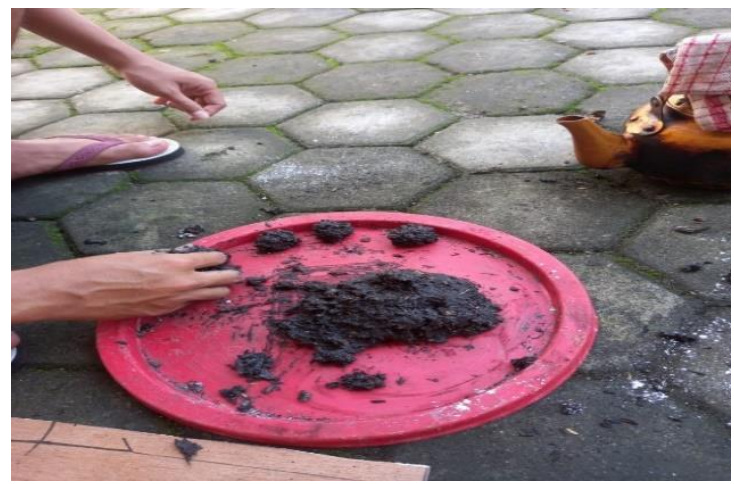

\section{F. Penjemuran Briket}

Briket yang sudah dibentuk tadi, kemudian dijemur selama dua hari hingga benar benar kering. Penjemuran briket ini bertujuan untuk mengurangi kadar air yang masih tersisa di dalam briket. Sehingga briket lebih mudah menyala.

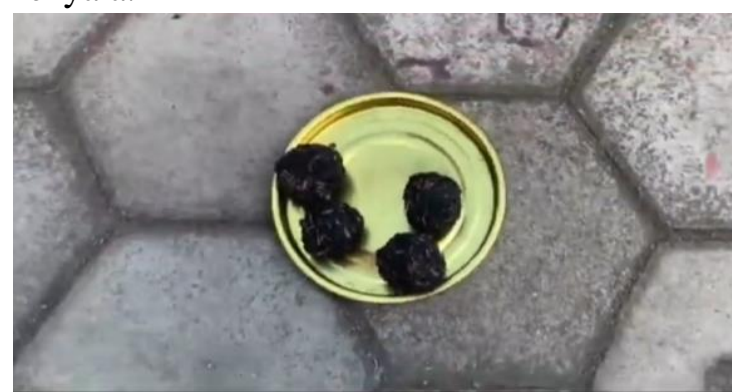




\section{G. Uji Coba Produk Briket}

Briket yang sudah dijemur selama dua hari, sudah siap untuk digunakan sebagai bahan bakar alternatif pengganti arang batok kelapa. Untuk menjadi arang Briket dibakar kurang lebih selama 10 menit dan setelah itu sudah dapat digunakan.

Berdasarkan tahapan-tahapan yang sudah dilakukan di atas, briket yang terbuat dari enceng gondok siap untuk digunakan.

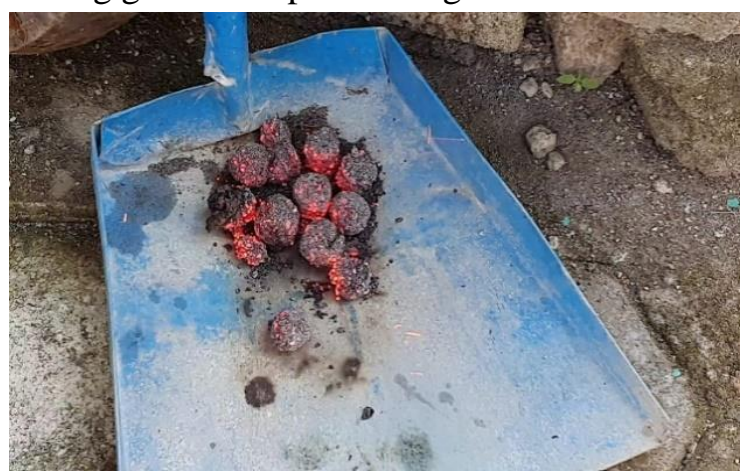

3.2. Potensi dan Prospek Enceng Gondok sebagai sebagai bahan bakar alternatif dalam bentuk Briket

\section{A. Manfaat Briket eceng gondok}

Briket eceng gondok dapat digunakan sebagai pengganti arang konvensional yang biasa kita pakai.

\section{B. Prospek Briket eceng gondok}

Briket eceng gondok mampu menjadi bahan bakar alternatif baru bagi masyarakat yang lebih ramah lingkungan serta dapat menjadi produk yang bernilai ekonomis.

\section{Kesimpulan}

Berdasarkan uraian diatas, dapat disimpulkan :

1. Eceng gondok merupakan salah satu gulma yang berkembang dengan pesat yang menyebabkan tertutupnya permukaan air sehingga dapat menyebabkan kerusakan ekosistem perairan di lingkungan tersebut.

2. Selain merugikan karena cepat menutupi permukaan air, eceng gondok juga bermanfaat karena mampu menyerap zat organik, anorganik serta logam berat lain yang merupakan bahan pencemar di ekosistem perairan tersebut.

3. Eceng gondok dapat dimanfaatkan sebagai bahan bakar alternatif (Briket) sehingga mampu mengurangi limbah eceng gondok dan memiliki nilai ekonomis bagi masyarakat sekitar.
4. Pada tahapan pembuatan briket untuk menambah ketahanan nyala api, Briket eceng gondok harus dicampurkan dengan bahanbahan seperti kulit biji kenari, sekam padi, ranting kayu yang sudah ditumbuk.

5. Agar Briket mudah dibentuk. Briket harus dicampurkan dengan tepung tapioka dan air hangat.

6. Agar Briket dapat menjadi arang saat proses pembakaran, dibutuhkan waktu selama 10 menit untuk kemudian arang Briket siap digunakan.

7. Manfaat dari Briket eceng gondok dapat digunakan sebagai pengganti arang konvensional yang biasa kita pakai. (mengingat lingkungan sekitar lokasi KKN memiliki potensi pariwisata)

8. Prospek kedepan dari briket eceng gondok ialah mampu menjadi bahan bakar alternatif baru bagi masyarakat yang lebih ramah lingkungan serta dapat menjadi produk yang bernilai ekonomis.

\section{Ucapan Terima Kasih}

Kami ucapkan terimakasih kepada semua pihak yang membantu dalam pengolahan produk minuman dan masker organik berbahan dasar kopi ini, baik yang berasal dari perangkat desa, ibu-ibu Kader dan remaja-remaja di Lingkungan Sapta Marga dan masyarakat di Lingkungan Sapta Marga.

\section{Daftar Pustaka}

Ali, Rahmat dkk. 2020. Pembuatan Masker Kopi Sebagai Produk Unggulan Kelompok Wanita Tani Desa Manggarai, Kecamatan Air Hitam, Kabupaten Lampung Barat. Jurnal Pengabdian Nasional Vol. 1 (1) 19 25.

https://jurnal.polinela.ac.id/index.php/JPN/i $\underline{\text { ndex. }}$

Ariyanto, E., Karim, M. A., \& Firmansyah, A. (2014). Biobriket Eceng Gondok (Eichhornia Crassipes) sebagai Bahan Bakar Energi Terbarukan.

Ariyanto, E. (2015, April). Studi Biobriket Eceng Gondok (Eichhornia 
Crassipes) sebagai Bahan Bakar Energi Terbarukan. In Seminar Nasional Teknik Kimia Kejuangan (pp. 6-1).

Balong, S., Isa, I., \& Iyabu, H. (2016). Karakterisasi Biobriket dari Eceng Gondok (Eichornia Crassipes) sebagai Bahan Bakar Alternatif. Jambura Journal of Educational Chemistry, 11(2), 147-152.

Billak, I. (2016). Pengaruh Variasi Temperatur Pembakaran terhadap Kualitas Biobriket Cangkang Kelapa Sawit (Doctoral dissertation, Politeknik Negeri Sriwijaya).

Dahdah, S. S. (2020). Pemanfaatan Sekam Padi Menjadi Briket Sebagai Energi Alternatif Studi Kasus Desa Wotansari-Balong

Panggang. DedikasiMU (Journal of Community Service), 2(1), 180-188.

Endra, Hermawan. 2018. "Mahasiswa UNDIP Ciptakan Mesin Pengolah Eceng Gondok Jadi Briket”, https://jateng.tribunnews.com/2017 /11/06mahasiswa-undip-ciptakanmesin-pengolah-eceng-gondokjadi-briket, diakses pada 1 Agustus 2021.

Fachry, A. R., Sari, T. I., Dipura, A. Y., \& Najamudin, J. (2010). Teknik Pembuatan Briket Campuran Eceng Gondok dan Batubara sebagai Bahan Bakar Alternatif bagi Masyarakat Pedesaan. In Seminar Nasional Perkembangan Riset dan Teknologi di Bidang Industri Ke16 (pp. TRTP-52). Fakultas Teknik Universitas Gadjah Mada.

Fachry, A. R., Sari, T. I., Dipura, A. Y., \& Najamudin, J. (2010). Mencari Suhu Optimal Proses Karbonisasi Dan Pengaruh Campuran Batubara Terhadap Kualitas Briket Eceng
Gondok.

Jurnal

Teknik

Kimia, 17(2).

Hartanto, Puji., Fathul, Alim. 2009. Optimasi kondisi operasi pirolisis sekam padi untuk - menghasilkan bahan bakar briket bioarang sebagai bahan bakar alternative. Jurusan teknik kimia fakultas teknik universitas diponegoro.

Hendra, D. (2011). Pemanfaatan eceng gondok (Eichornia crassipes) untuk bahan baku briket sebagai bahan bakar alternatif. Jurnal Penelitian Hasil Hutan, 29(2), 189-210.

Pratama, Y. Y. (2019). Pemanfaatan Ampas Kulit Singkong Dan Tongkol Jagung Sebagai Bahan Bio Briket Arang Dengan Perekat Tepung Tapioka Terhadap Nilai Kalor Dan Laju Pembakaran Fakultas Teknologi (Doctoral dissertation, Institut Teknologi Nasional Malang).

Prihatiningtyas, E., \& Asysyifa, S. (2020, May). Pemanfaatan Eceng Gondok (Eichornia Crassipes) Untuk Mengurangi Pencemaran Air Dan Meningkatkan Ekonomi Masyarakat Desa Tungkaran. In Pro Sejahtera (Prosiding Seminar Nasional Pengabdian kepada Masyarakat) (Vol. 2, No. 1).

Rachmayanti, novie. 2019. "5 Manfaat Eceng Gondok yang Jarang Diketahui", https://www.bola.com/ragam/read/ 41376 5/5-manfaat-eceng-gondokyang-jarang diketahui-bantu-obatisakit-gigi, diakses pada 1 Agustus 2021.

Ratnani, R. D. (2012). Kemampuan kombinasi eceng gondok dan lumpur aktif untuk menurunkan pencemaran pada limbah cair industri tahu. Jurnal Ilmiah Momentum, 8(2). 
Serevina, V., Pambudi, R. D., \& Nugroho, D.

A. (2021). The Usaha Briket Biomassa Sebagai Sarana

Pengurangan

Bahan Bakar Fosil Dan Mengurangi

Limbah. Jurnal

Pengabdian

Masyarakat Sains

dan

Apliaksinya, 1(1), 1-5.

Sibarani, F.A.S. (2016). Pengaruh Perbandingan Massa Eceng Gondok

Dan Tempurung Kelapa Serta

Kadar Perekat Tapioka Terhadap

Karakteristik Briket. Jurnal Teknik

Kimia USU, 5(1), 20-26 